\title{
タンデム超音波探傷による K開先溶接部の品質管理と疲労き裂検出
}

\author{
三木 千壽 1 ・白旗 $\quad$ 弘実 $^{2}$. 山口 亮太 ${ }^{3}$ 小下 幸治 4 ・柳沼 安俊 5 \\ 1フェロー会員 東京工業大学 副学長 理工学研究科土木工学専攻 ( $\mathrm{T}$ 152-8552 東京都目黒区大岡山 2-12-1) \\ E-mail:miki@cv.titech.ac.jp \\ 2 正会員 武蔵工業大学 助教授 工学部都市基盤工学科 ( $\bar{\top} 158-8557$ 東京都世田谷区玉堤 1-28-1) \\ E-mail:hshiraha@sc.musashi-tech.ac.jp \\ 3学生会員 東京工業大学大学院 (研究時) 東日本高速道路 (株) ( ⿳ 厂干 359-0012 所沢市大字坂之下 761-1) \\ 4学生会員 東京工業大学大学院 理工学研究科土木工学専攻 博士課程 ( 152-8552 東京都目黒区大岡山 2-12-1) \\ 5正会員 (株) 東京鐵骨橋梁 生産技術課 (广 302-0038 茨城県取手市下高井 1020)
}

\begin{abstract}
$\mathrm{K}$ 型開先溶接は橋梁の継手の中でもっとも基本的な継手の一つである．K 型開先溶接は完全溶け込み溶接で 行われることが規定されている。しかしながら，ルート部に溶け込み不良が生じるといった問題が生じること がある. 完全溶け込み溶接の品質管理としてタンデムアレイ探触子による超音波探傷試験を行った。面状欠陥 からのエコーを受信しやすいタンデムアレイ探触子を適用した．板厚や未溶着部の高さをパラメータとした試 験体を作成し, 実験を行った。 開口合成による未溶着部の画像化を行い, 未溶着部の寸法を推定した. 未溶着 部のある継手を有する構造物が供用され，未溶着部が検出された場合，未溶着部から疲労き裂が進展している かどうかはきわめて重要な問題である．未溶着部と未溶着部より進展するき裂の識別を試みた.
\end{abstract}

Key Words : nondestructive evaluation, automatic ultrasonic testing, $K$ groove weld, weld defect, full penetration, incomplete penetration

\section{1.はじめに}

$\mathrm{K}$ 開先溶接は橋脚隅角部や横栴接合部など，橋梁にお けるもつとも基本的な継手の一つである. 重要な継手の $\mathrm{K}$ 開先溶接は疲労の問題から図-1(a)に示すようなルー トフェイスを残さない完全溶込溶接が適用されている. 完全溶込溶接においては, 数 $\mathrm{mm}$ のルートフェイスを 残した開先で溶接を行い，裏ガウジング処理を施した 後, もう一方の開先を溶接する手順で行われる。しか しながら，開先の精度が悪い場合や裏ガウジングが不 十分になるなど施工管理がよくない場合には，図-1(b) に示すように，ルートフェイスが残るといった問題が 生じる.ルートフェイスが残された継手においては溶 接未溶着部より疲労き裂が発生し進展する可能性があ る 1),2),3),4)ので, 溶接部の品質管理はきわめて重要で ある。また，既設構造物に対する非破壊検査において， $\mathrm{K}$ 開先溶接の内側に面状の欠陥を検出した場合，それ が溶接時に残された未溶着部なのかあるいはその端部 から疲労き裂が発生し進展しているのかについては，そ の後のメンテナンスを考える上で極めて重要な情報と なる.

溶接部の品質管理手法としては超音波探傷試
験 5),6),7),8),9),10）があげられる. 従来の溶接部の品質 管理手法であった放射線透過試験では放射線が周囲に 影響を及ぼすことや，梁と柱の接合部などにおいては 透過フィルムを柱内部に置くことができないことによ り適用はきわめて困難である.

梁と柱の接合部における $\mathrm{K}$ 開先溶接部に超音波探傷 試験を適用することを想定した場合, 開先角度が大き いことと柱が存在することから探傷できる範囲が限ら れることになる. また, 従来の一探触子による斜角探傷 法で面状欠陥である溶接未溶着部を検出する場合, 入 射波が久陥で鏡面反射され，反射波が指向性をもつた めに検出が難しくなる.

本研究では超音波探傷試験によって $\mathrm{K}$ 開先溶接の溶 接部の未溶着部を確実に検出すること，およびその寸 法を推定することを第一段階の目的としている.さら に未溶着部が検出された際に，そこから疲労き裂が発 生しているか, もしくは溶接欠陥のみで疲労き裂が生 じていないかを超音波探傷により判定することを第二 段階の目的としている.

ここでは面状欠陥である溶接未溶着部を検出するた めにタンデムアレイ探触子を用いた. タンデムアレイ 探触子は著者らが開発したもので ${ }^{11)}$, 面状欠陷の検出 
(a)

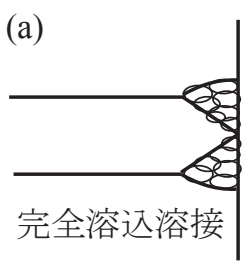

(b)

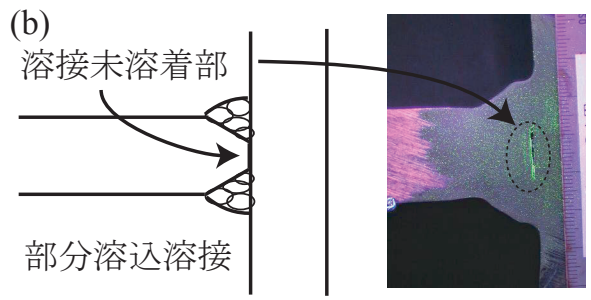

図-1 本研究で対象とする溶接継手と溶接欠陥

にはすぐれた性能が得られている，開口合成による画 像化を行った。

\section{2. 実験概要}

\section{(1) 実験システム}

本研究で用いた実験システムを図-2 に示す、システ ムは 10 連タンデムアレイ探触子, 超音波探傷器, 波形 分配器, パーソナルコンピュータより構成される. タ ンデムアレイ探触子は同じ特性をもった探触子 10 個を 縦に並べたものである，構成している個々の探触子は 屈折角 70 度, 中心周波数 $5 \mathrm{MHz}$ のものである. 1 チャ ンネルから 10 チャンネルまでの探触子で送信, 受信を 行うことで送信および受信で $10 \times 10=100$ のエコー波形 を得ることができる．超音波探傷器ではパルス波を発 生させる. パルス波は波形分配器に送られる. 波形分 配器ではパルス波を送信 10 通り, 受信 10 通りに分配 する. $10 \times 10$ 通りの波形を 2 秒ほどで取得することが 可能である. パーソナルコンピュータには波形を取得 するためのプログラムおよび取得した波形を画像化す るためのプログラムの 2 種類のプログラムが搭載され ている. 画像化プログラムでは波形取得後にリアルタ イムに特定の送受信の探触子の組み合わせの波形を抽 出したり, 特定の組み合わせの波形のみを使って, 画 像を再構成することができる.

\section{(2) 試験体}

実験で用いた試験体を図-3に示寸、試験体は梁, 柱 接合部の梁フランジおよび柱フランジをモデルとして いる.はさみ板の両側の 2 か所の $\mathrm{K}$ 開先溶接のうち, 一方は完全溶込溶接, もう一方は部分溶込溶接である. 試験体形状のパラメータとして, 梁フランジの厚さと 溶接未溶着部の高さがある. 図-3 に示すように, 板厚 $25 \mathrm{~mm}$ の板からなる試験体の未溶着部高さは $9 \mathrm{~mm}$ およ び $15 \mathrm{~mm}$ である. 板厚 $40 \mathrm{~mm}$ の試験体においては未溶
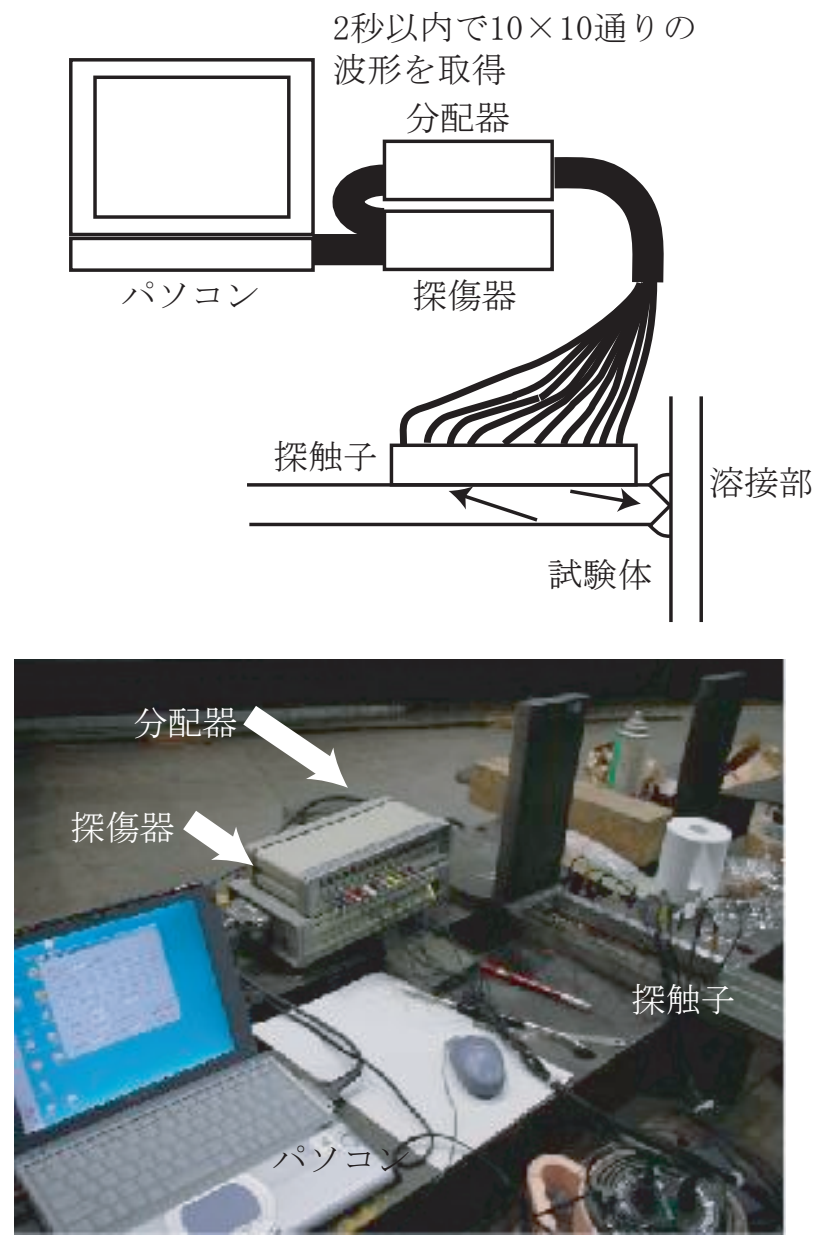

10連タンデムアレイ探触子

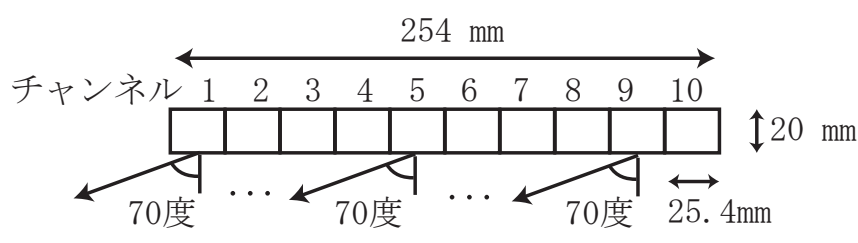

各チャンネルからの入射波 屈折角 70 度 周波数 $5 \mathrm{MHz}$

図-2 タンデムアレイ探触子による実験システム

着部高さは $11 \mathrm{~mm}$ である. $\mathrm{K}$ 開先の角度は 60 度であ る. 溶接による余盛は除去されていない. 著者らによ るタンデムアレイ探触子による未溶着部検出に関する 検討はすでにあるが 12), ここでは試験体板厚や未溶着 部の高さをパラメータとしている点が既往の研究と異 なっている.

\section{(3) 試験概要}

試験概要を図-4に示寸，溶接止端部に探触子の前面 がくるように配置し, 送信 10 通り, 受信 10 通りの 100 通りの波形を取得した。 その後, 探触子を溶接部より $2 \mathrm{~mm}$ だけ離し，100 通りの波形を取得した．同様にし て, 探触子を $24 \mathrm{~mm}$ まで移動させ, 各探触子位置にお いて 100 通りの波形を取得した. 

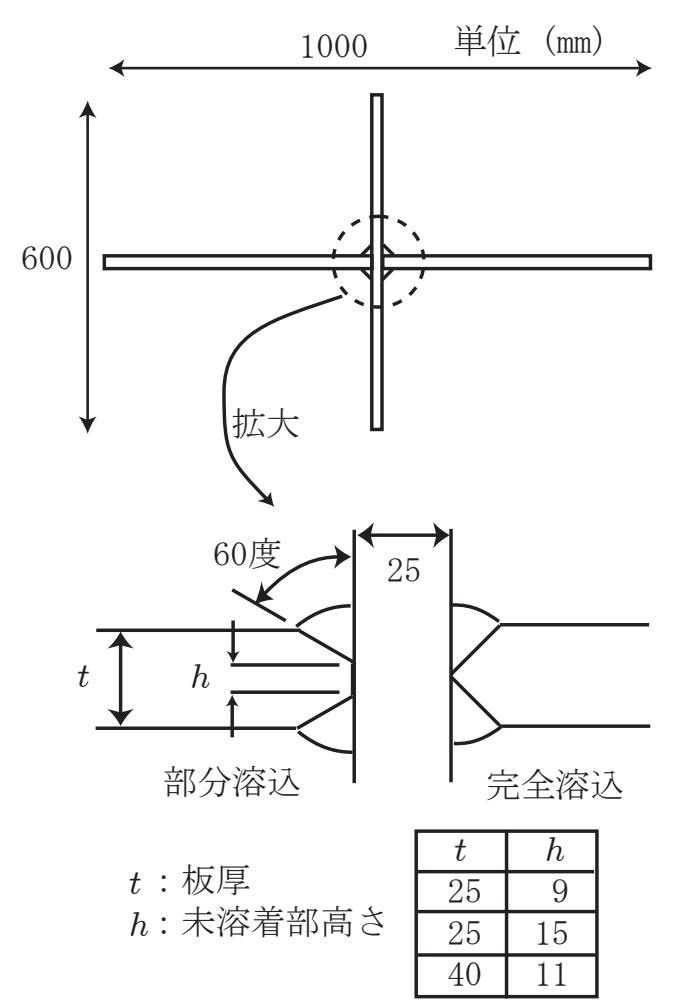

図-3 実験で用いた十字継手試験体

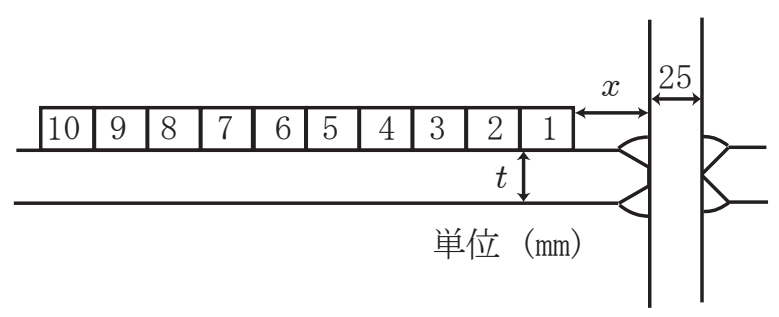

$x$ : 柱端面から探触子までの距離 $(\mathrm{mm})$ $x$ は探触子接近限界距離から $2 \mathrm{~mm}$ おきに $24 \mathrm{~mm}$ 移動 各探傷位置 $x$ で100通りの波形を取得 $t:$ 板厚

\begin{tabular}{|r|c|}
\hline$t$ & $x$ \\
\hline 25 & $15-39$ \\
\hline 40 & $24-48$ \\
\hline
\end{tabular}

図-4 試験概要

\section{3. 欠陥エコーの検出性}

厚さ $25 \mathrm{~mm}$ ，未溶着部高さ $9 \mathrm{~mm}$ の試験体で実験を 行った. 図-5(b) に示すように，探触子の前面を溶接止 端部にあたる位置に設置し，得られた波形を図-5(a)に 示す. 図-5(a)の横軸は送信チャンネルからの距離を, 縦軸はエコー高さを示している。送信探触子からの距 離は，波動伝播時間と鋼中の横波波速より算出したも のである。エコー高さは各波形が重ならないようにず らして示している. 図-5(a) は送信が 1 チャンネルの場 合を示しているが，受信チャンネルが 4 および 5 のと きに大きなエコーが得られていることがわかる。

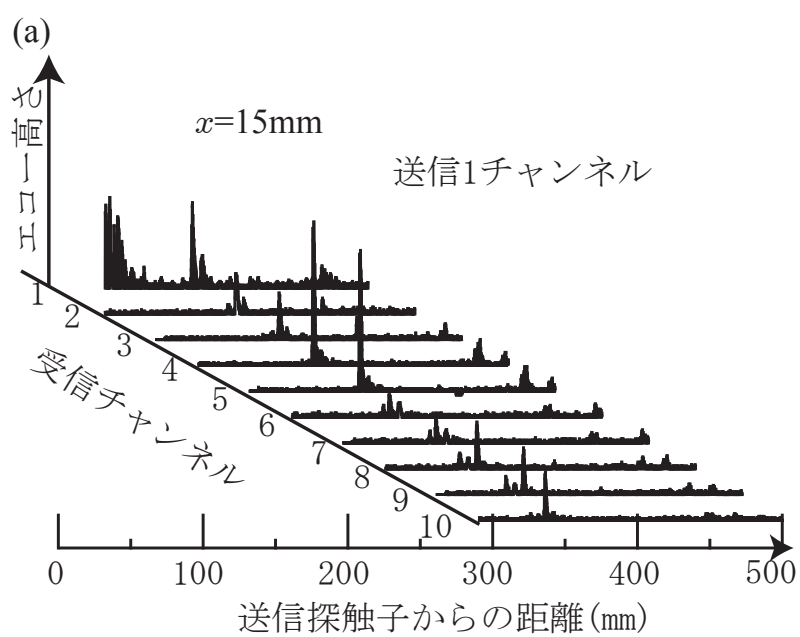

(b)

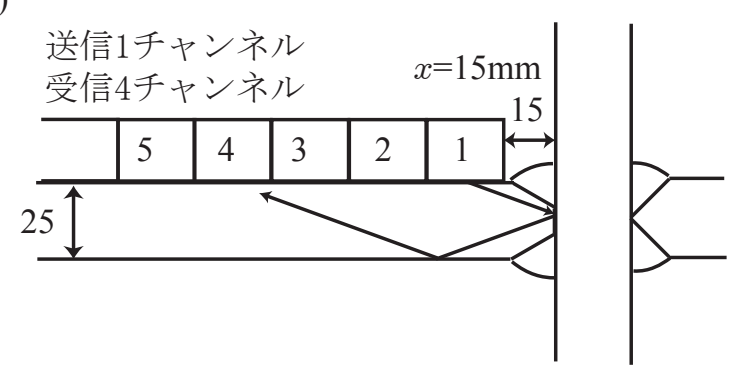

図-5 実験で得られた波形 板厚 $25 \mathrm{~mm}$ 送信 1 チャンネル

図-5(b) に示すように，波動伝播距離および試験体形 状を考慮すると，送信 1 チャンネルから入射された波は 未溶着部で鏡面反射したのち，底面で反射され，チャン ネル 4 および 5 で受信されたものであると考えられる.

図-6(a) は厚さ $40 \mathrm{~mm}$ ，未溶着部高さ $11 \mathrm{~mm}$ の試験 体で得られた波形である。探触子の前面が溶接止端部 に来る位置に探触子をおいている. 図-6(a)の縦軸およ び横軸は図-5(a) と同じである。図-6(a) は送信チャン ネルが 2 の場合であるが，受信チャンネルが 7 および 8 の組み合わせのときに大きなエコーが得られている. 図-6(b) に示すように，送信 2 チャンネル，受信 7 チャ ンネルの組み合わせで未溶着部で鏡面反射された波が 得られやすいことがわかる.

図-7 に送信 1 チャンネル，受信 4 チャンネルで得ら れた波形の中でもつとも振幅の高いエコーの高さと探 触子位置との関係を示す. 図-7 の横軸は図-4に示され るように，柱端面と探触子前面の距離 $x$ である. 図-7 の縦軸は試験体と同一の厚さの板のこば面で反射され たエコーで，探触子を前後走査し，もつとも高いエコー 高さを基準とした相対高さとしている. 図-7(a) は厚さ $25 \mathrm{~mm}$, 未溶着部高さ $9 \mathrm{~mm}$ の試験体の結果である. 図7 (b) は厚さ $40 \mathrm{~mm}$, 未溶着部高さ $11 \mathrm{~mm}$ の試験体の結 果であり, 送信 2 チャンネル, 受信 7 チャンネルの組 み合わせの波形である。

図-7(a) に示すように，厚さ $25 \mathrm{~mm}$ の試験体におい て，柱端面と探触子との距離が $30 \mathrm{~mm}$ より短かければ 
(a)

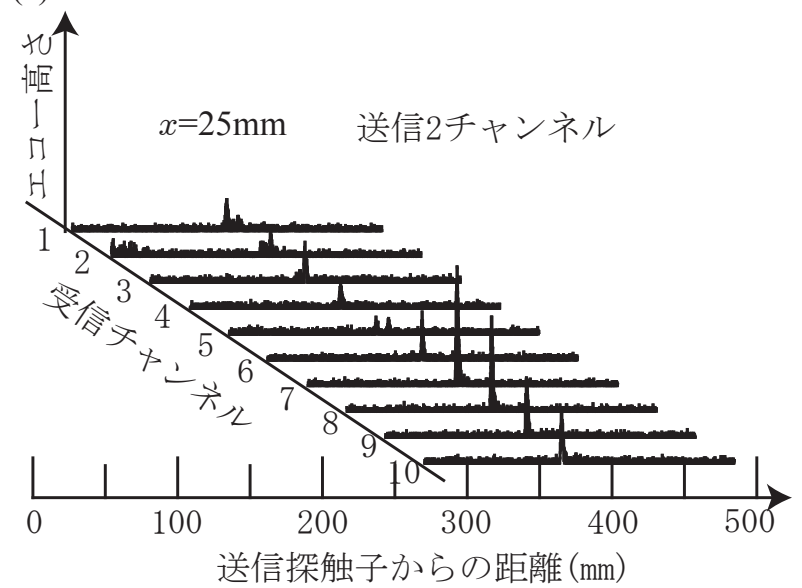

(b)

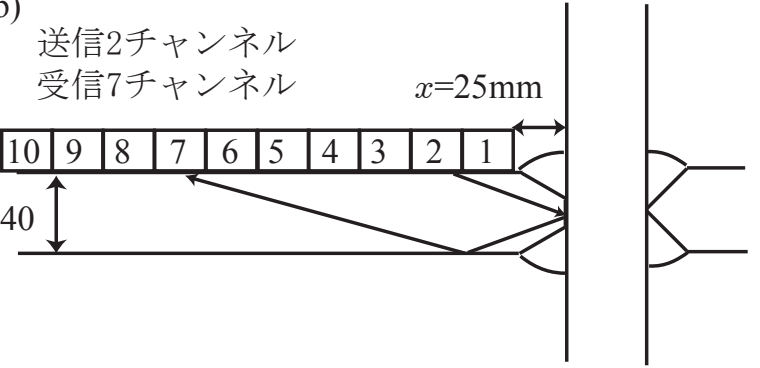

図一6 実験で得られた波形 板厚 $40 \mathrm{~mm}$ 送信 2 チャンネル

エコー高さはそれほど変化していない，厚さ $40 \mathrm{~mm}$ の 試験体に対しても柱端面と探触子との距離が $34 \mathrm{~mm}$ 程 度までならばエコー高さはそれほど低くならない。余 盛があるので，探触子の最短接近距離は厚さ $25 \mathrm{~mm}$ の 試験体で約 $15 \mathrm{~mm}$ ，厚さ $40 \mathrm{~mm}$ の試験体で約 $25 \mathrm{~mm}$ で あった. タンデムアレイ探触子による探傷においては, 溶接止端から $10 \mathrm{~mm}$ 程度以内に探触子を設置すれば, 欠陷エコーを得ることができるといえる.

\section{4. 画像化結果}

開口合成による画像化を行った ${ }^{11)}$ 。画像化に際し， はじめに画像化領域を設定する。画像化領域は図-8に 示すように継手部の未溶着部が発生すると思われる部 分を中心として前後に $25 \mathrm{~mm}$ ，板厚に相当する高さを領 域の高さとした。領域のメッシュ分割サイズを $0.5 \mathrm{~mm}$ とした。画像化の手法や想定される超音波伝播経路は これまでの検討 ${ }^{11)}$ と同様である.

図-9 に画像化結果を示す．図-9(a) は厚さ $25 \mathrm{~mm}$ ，未 溶着部高さ $15 \mathrm{~mm}$ の試験体である，探触子と柱端面と の距離 $18 \mathrm{~mm}$ の位置で得られた 100 通りの波形を用い ている。再構成領域の中央で未溶着部分に相当する位 置に像が得られている.未溶着部高さは $18 \mathrm{~mm}$ と推定 されているが，実際の未溶着部より $3 \mathrm{~mm}$ ほど高く推定 されている。その理由として，下端側で得られた像は 試験体底面と未溶着部で構成される擬似的なコーナー 反射の影響を受けたものと考えられる.

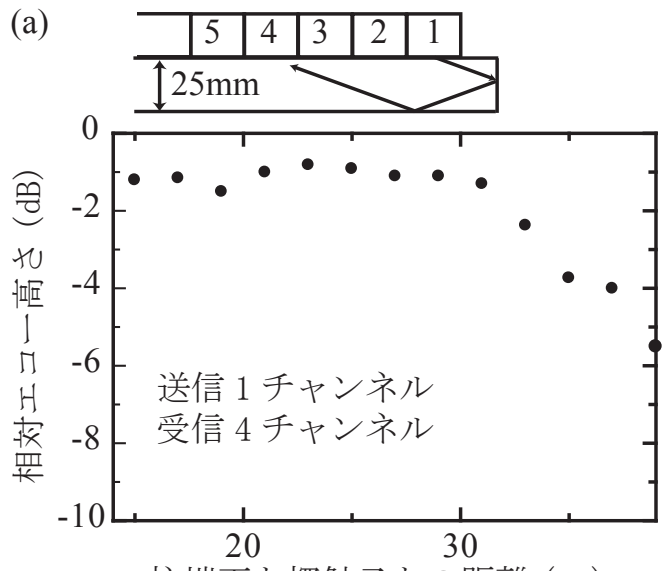

柱端面と探触子との距離 $(\mathrm{mm})$
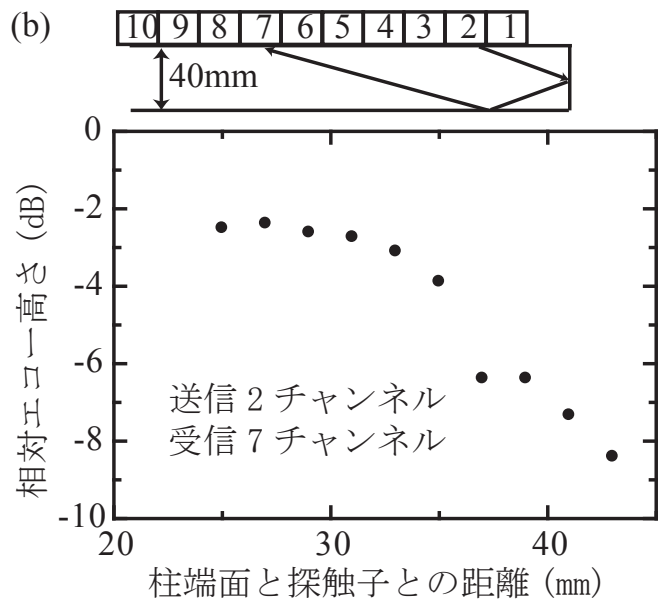

図-7 欠陥エコー高さと探触子位置

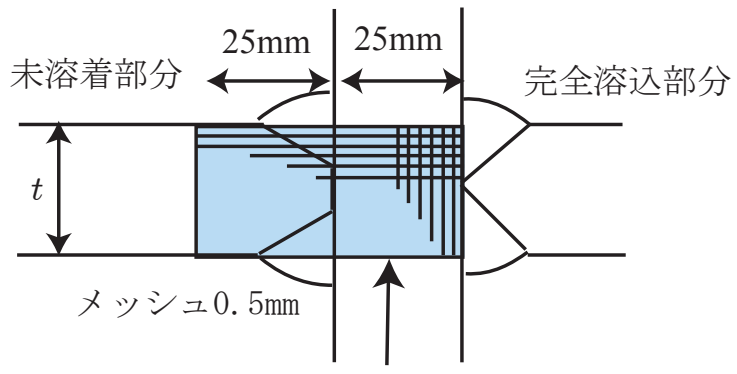

再構成領域

図-8 画像化領域

図-9(b) は厚さ $25 \mathrm{~mm}$ ，未溶着部高さ $9 \mathrm{~mm}$ の試験体 の画像化結果である. 探触子と柱端面との距離は $15 \mathrm{~mm}$ である。図の結果では未溶着部は $9 \mathrm{~mm}$ であり, 実際と よく一致している.

図-9(c) は厚さ $40 \mathrm{~mm}$ ，未溶着部高さ $11 \mathrm{~mm}$ の試験体 の画像化結果である. 探触子と柱端面との距離は $24 \mathrm{~mm}$ である. 未溶着部のあると思われる位置に像が得られて いる．未溶着部高さは $12.5 \mathrm{~mm}$ であり，若干大きめでは あるが，実際のものとほぼ一致している。また， $1 \mathrm{~mm}$ であったが，未溶着部の像が実際の未溶着部より下側 に得られた。 
(a) 板厚 $t=25 \mathrm{~mm}$ 未溶着部高さ $h=15 \mathrm{~mm}$

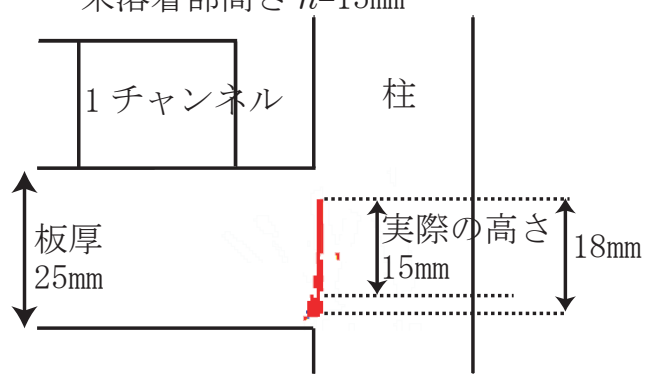

(b) 板厚 $t=25 \mathrm{~mm}$

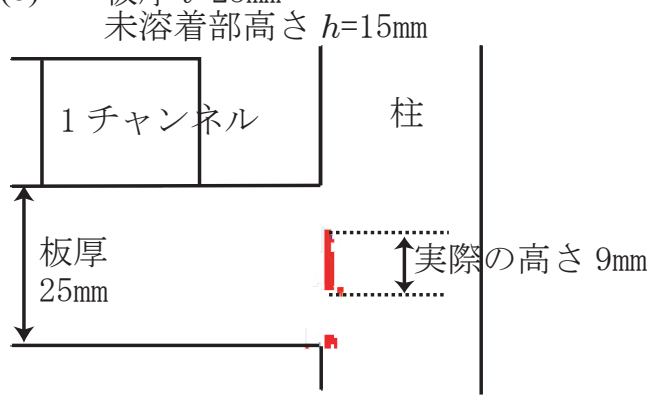

(c) 板厚 $t=40 \mathrm{~mm}$ 未溶着部高さ $h=11 \mathrm{~mm}$

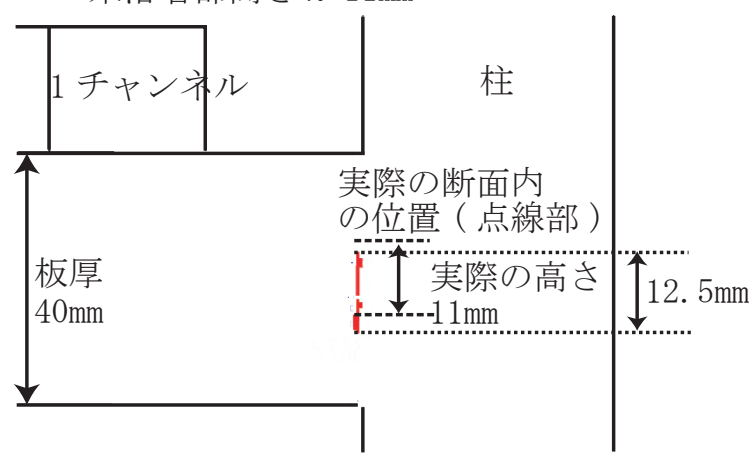

図-9 開口合成による画像化結果 : (a) 板厚 $t=25 \mathrm{~mm}$ 未溶 着部高さ $h=15 \mathrm{~mm}, \quad(\mathrm{~b})$ 板厚 $t=25 \mathrm{~mm}$ 未溶着部高さ $h=9 \mathrm{~mm}$, (c) 板厚 $t=40 \mathrm{~mm}$ 未溶着部高さ $h=11 \mathrm{~mm}$

図-9(a) および (b) において，欠陥像は面反射された エコー，つまり図-5 における送信 1 チャンネル，受信 4 チャンネルで得られたエコーにより再構成されている. その他に送信，受信ともに 1 チャンネルの組み合わせ のエコーも像の再構成の寄与に大きかった。 このエコー は未溶着部上端部からの端部エコーであると考えられ る。また，送信，受信ともに 2 チャンネルの組み合わ せで得られたエコーが結ぶ像は未溶着部下端付近に像 を結んでおり，下端部エコーであると推定される。

図-9(c) の像においても, 送信 2 チャンネルおよび受 信 7 チャンネルの組み合わせで得られたエコーによる 像が未溶着部で面反射されたものであった。 上端部お よび下端部と思われる位置からのエコーも受信されて いた. 送受信ともに 1 チャンネルの場合, 上端部エコー が，送受信ともに 2 チャンネルの場合，下端部エコー が得られた。

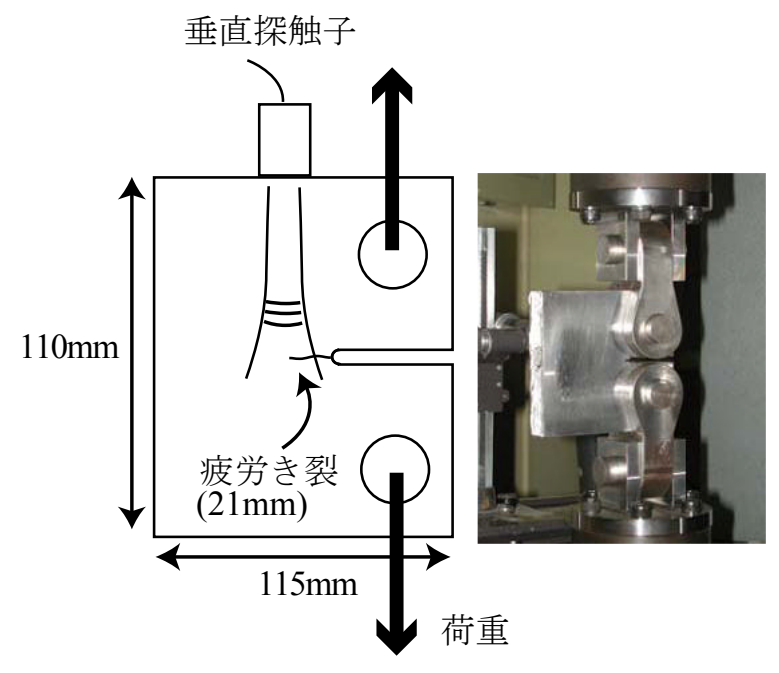

図-10 コンパクトテンション試験片による疲労試験

いずれの場合においても，像は未溶着部で面反射さ れたエコーおよび未溶着部上下端からの端部エコーに より得られている. 端部エコーは面反射されたエコー より $3 \mathrm{~dB}$ から $8 \mathrm{~dB}$ 低いものとなっている.

タンデムアレイ探触子を用いれば，走査することな く面反射エコーを受信することができる，図-5，図-6 および図-9 はタンデムアレイ探触子の高い検出性能を 示しているといえる.

\section{5. 未溶着部と疲労き裂の分離}

\section{（1） コンパクトテンション試験片のき裂開閉ロ}

既設構造物中の溶接部に未溶着部を検出した際に, 疲 労き裂がそこから進展しているのか，もしくは単に未 溶着のままでき裂が進展していないのかということは 大きな問題である。疲労き裂は, 荷重載荷により開閉 口挙動を示すことが知られている ${ }^{13), 14)}$. したがって, 超音波探傷により欠陥が溶接欠陥なのか疲労き裂なの かを識別するには, 荷重載荷による開閉口挙動を検出 することが一つの方法であると考えられる。ここでは 最初に, コンパクトテンション試験片を用いて疲労試 験を行い，それによって発生および進展させた疲労き 裂について超音波探傷試験を行った。

疲労試験状況を図-10 に示寸. 疲労試験は, 引張最大 荷重 $41 \mathrm{kN}$ 最小荷重 $1.0 \mathrm{kN}$ の部分片振り試験を行い, 約 $21 \mathrm{~mm}$ の疲労き裂について垂直探傷を行った．探傷で は，き裂の先端に超音波が当たるようにし，試験機の 載荷荷重を $0 \mathrm{kN}$ から $40 \mathrm{kN}$ の間で変化させて測定をし た. 探触子は直径 $10 \mathrm{~mm}$, 周波数 $5 \mathrm{MHz}$ の垂直探傷用 のものを用いている.

図-11は，荷重を変化させながらき裂先端を測定した ときの, 荷重とエコー高さの関係である，き裂からの エコー高さは, JIS の標準試験片による基準エコーとの 相対エコー高さで表している. 図-11 より，20kN 付近 

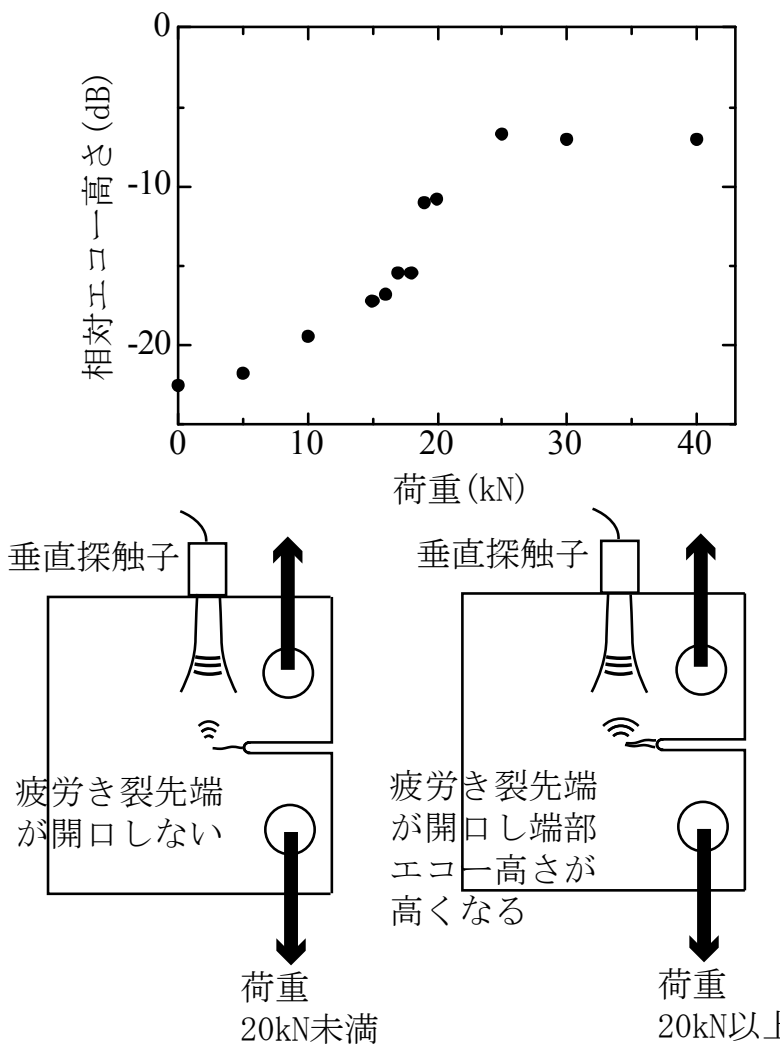

図-11 コンパクトテンション試験片の荷重および疲労き裂 からのエコー高さの関係

でエコー高さが急激に上昇している． $20 \mathrm{kN}$ 前後で疲労 き裂が開閉口しているといえる。き裂面が閉じている 場合は，超音波が透過しやすくなるのでエコーが低く なる。き裂面が開いている場合は超音波がき裂面を透 過せずにそこで反射されるのでエコーは高くなる，超 音波探傷によって開閉口の現象を捕えることができて いると考えられる.

\section{（2）十字継手試験体による実験}

十字溶接継手試験体に対して，き裂の開閉口現象を とらえ, 疲労き裂の識別を試みた。疲労試験を実施し 未溶着部より疲労き裂を発生させた。 下限荷重 $10 \mathrm{kN}$ の 部分片振り試験を行った。荷重振幅は $100 \mathrm{kN}$ である. 試験概略を図-12 に示す，実験では厚さ $25 \mathrm{~mm}$ の梁フ ランジ部で, 未溶着部高さ $9 \mathrm{~mm}$ の試験体, および厚さ $25 \mathrm{~mm}$ の梁フランジ部で，未溶着部高さ $15 \mathrm{~mm}$ の試験 体を用いた．試験体の幅は $50 \mathrm{~mm}$ であるが， $100 \mathrm{kN}$ を 載荷すると, 試験体に発生する応力は $80 \mathrm{MPa}$ 程度とな る.これは実際の橋梁に作用している応力と同程度で ある 1)

未溶着部高さ $15 \mathrm{~mm}$ の試験体は繰り返し回数 46 万 回で溶接ルート部からのき裂により破断した。破断ま での 23 万載荷時に探傷試験を行った．探傷試験では約 $0 \mathrm{kN}$ から $80 \mathrm{kN}$ まで $10 \mathrm{kN}$ おきに荷重を変化させ，各荷

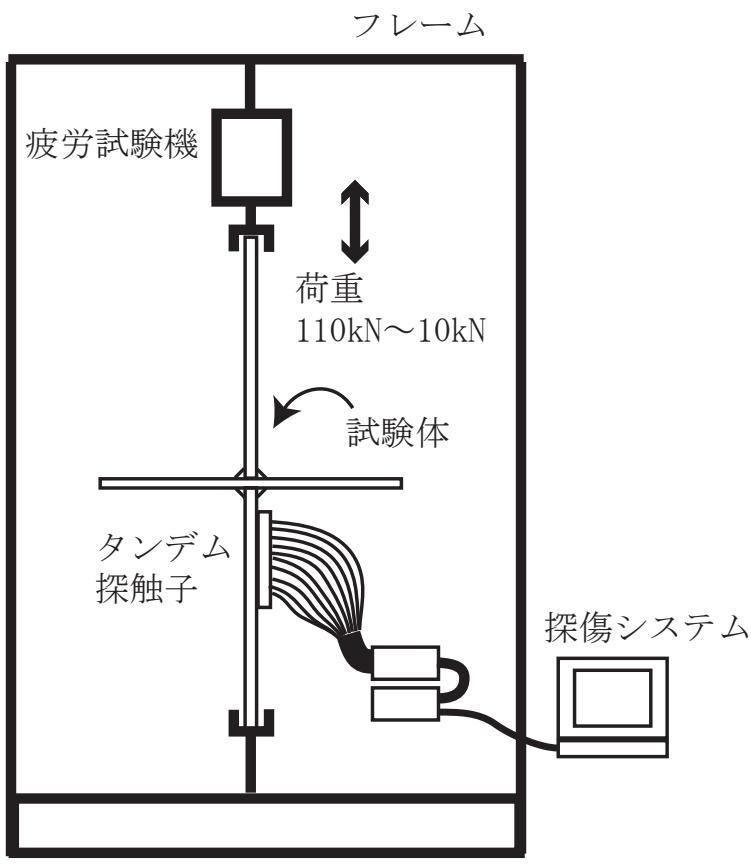

図-12 十字継手による疲労試験

重載荷時に 100 通りの波形を取得した.

図-13 および図-14 は載荷回数 23 万回の段階で，そ れぞれ $80 \mathrm{kN}$ 載荷時と非載荷時において得られた波形 を示している. 図-13 は送信 2 チャンネル，受信 2 チャ ンネルの組み合わせであり，図-13(a) は荷重 $80 \mathrm{kN}$ 載 荷時, 図-13(b) は非載荷時の波形である。図-14 は送 信 1 チャンネル，受信 4 チャンネルの組み合わせであ り, 図-14(a) は荷重 $80 \mathrm{kN}$ 載荷時, 図-14(b) は非載荷 時の波形である。縦軸はエコー高さを，横軸は送信探触 子からの波動伝播距離を示している．図-13においては 送信探触子より $150 \mathrm{~mm}$ の位置にエコーが見られるが， 載荷時の図-13(a) と非載荷時の図-13(b) で振幅が異な る.図-14 は $175 \mathrm{~mm}$ の位置にエコーが見られるが，載 荷時の図-14(a) と非載荷時の図-14(b) においても振幅 がほぼ同じである。

図-15 は荷重とエコー高さの関係を示したものであ る. エコー高さは最大時を基準として $\mathrm{dB}$ で示してい る. 図-15(b) は送信 2 チャンネル, 受信 2 チャンネル の組み合わせ，図-15(c) は送信 1 チャンネル，受信 4 チャンネルの組み合わせである。図-15(b) においては 荷重とともにエコー高さが高くなっているのがわかる. 荷重 $0 \mathrm{kN}$ と $80 \mathrm{kN}$ においてはおよそ $3 \mathrm{~dB}$ ほどの違いで ある.一方で図-15(c) においてはエコー高さは荷重に よりほとんど変化しないことがわかる。図-15(a)に 23 万回載荷時のビーチマークのスケッチを示す. 溶接未溶 着部上下端より疲労き裂が進展している. 図-15(a)に は探傷位置も示しているが，探傷位置においては，疲 労き裂は母材板厚と同じくらいにまで進展している.

送信 2 チャンネル，受信 2 チャンネルの組夕合わせで 得られたエコーは開閉口挙動をとらえており, エコー 

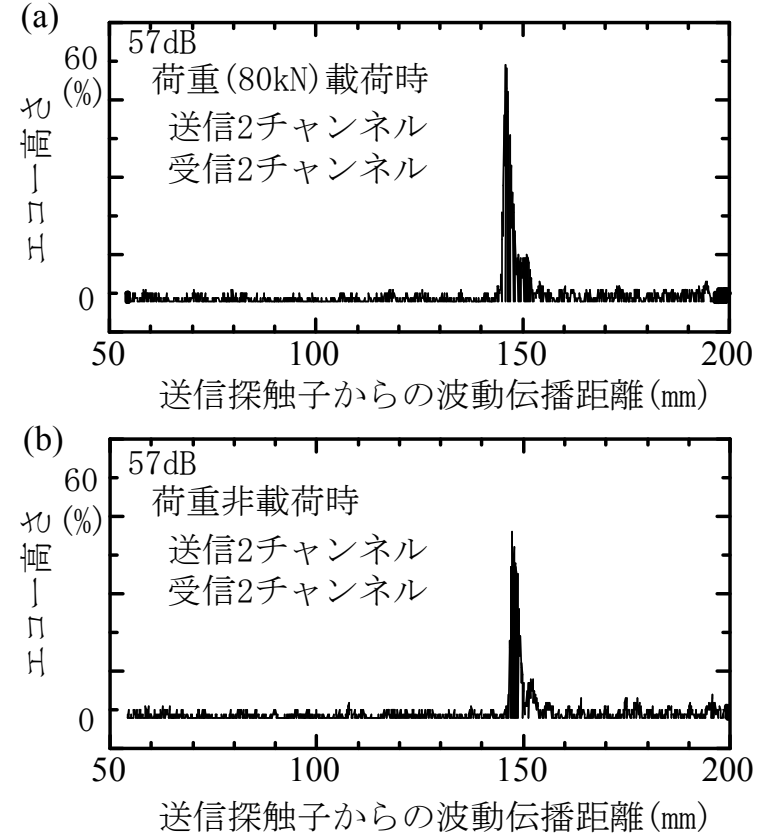

図-13 荷重によるエコー高さの変化 送信 2 チャンネル 受信 2 チャンネル

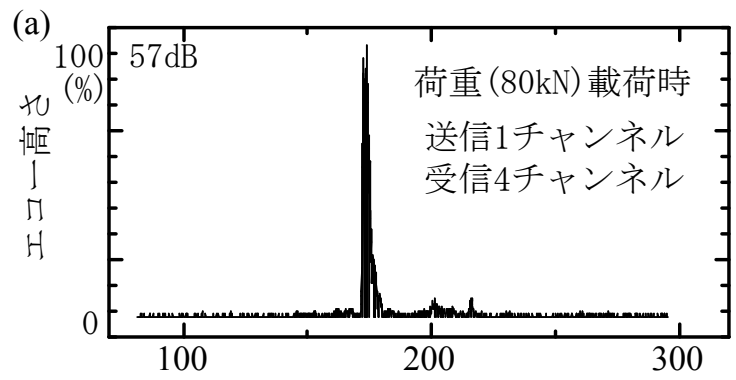

送信探触子からの波動伝播距離 $(\mathrm{mm})$

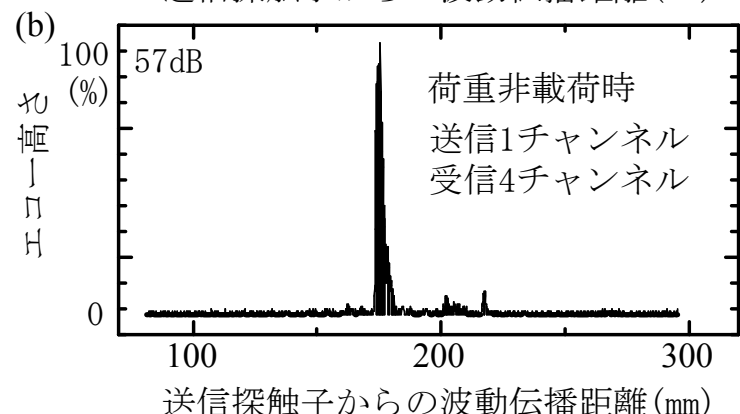

図-14 荷重によるエコー高さの変化 送信 1 チャンネル 受信 4 チャンネル

の現れている波動伝播距離 $150 \mathrm{~mm}$ であることを考慮 すると，溶接未溶着部より発生し進展した疲労き裂の 下端部エコーを受信しているものと考えられる。送信 1 チャンネル，受信 4 チャンネルの組み合わせで得られ たエコーは疲労き裂先端からのエコーではなく，面状 欠陥で鏡面反射されたエコーであり，荷重載荷による 振幅の変化はそれほどなかったと考えられる.

板厚 $25 \mathrm{~mm}$ ，未溶着部高さ $9 \mathrm{~mm}$ の試験体は溶接ルー 卜部から疲労き裂が進展し，350 万回の荷重載荷時に破 (a)

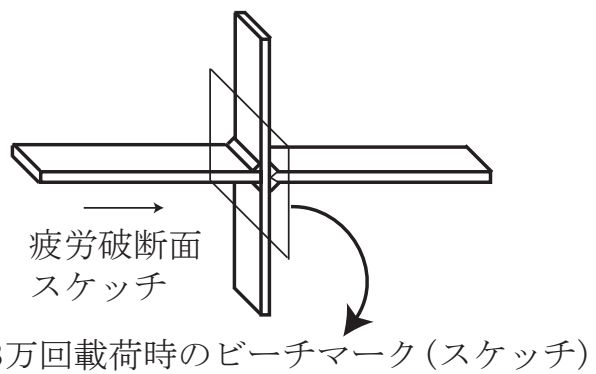

探傷位置 A-A'

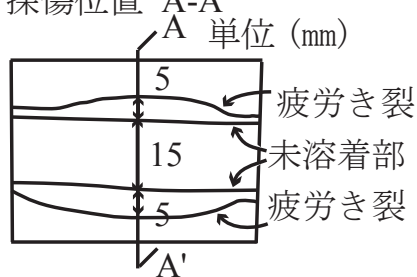

(b)

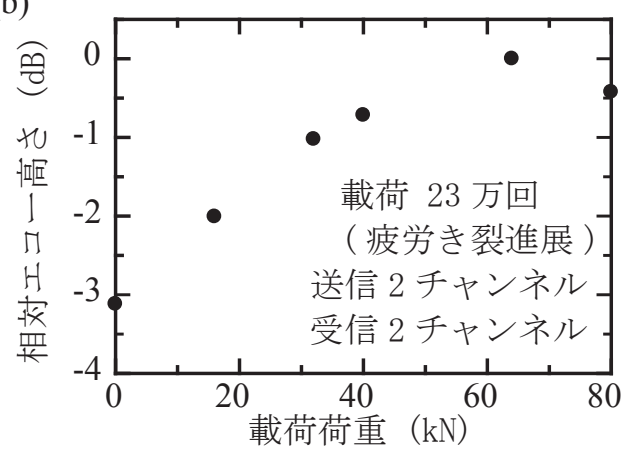

(c)

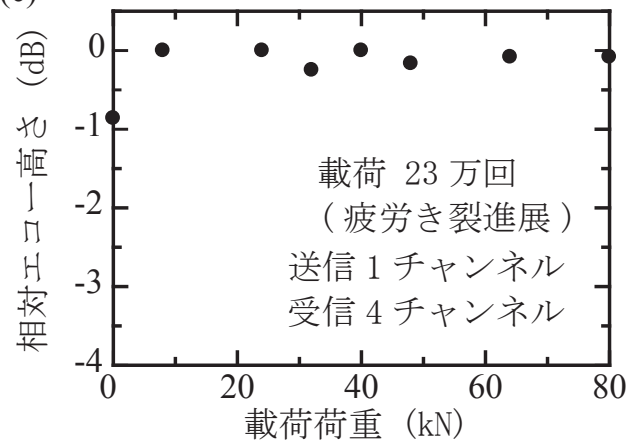

図-15 荷重とエコー高さ: 板厚 $t=25 \mathrm{~mm}$ ，未溶着部高さ $h=15 \mathrm{~mm}$ 試験体 23 万回載荷後

断した。疲労試験の最中にはビーチマーク試験および 探傷試験を実施した. 30 万回および 235 万回の載荷を 行ったあとの探傷試験結果を示す。探傷試験ではほぼ $0 \mathrm{kN}$ から $100 \mathrm{kN}$ まで， $20 \mathrm{kN}$ ずつ荷重を載荷させ，各 荷重で 100 通りの波形を取得した。画像化の際にわかつ た上端部エコーと思われる送受信ともに 1 チャンネル, および下端部エコーと思われる送受信ともに 2 チャン ネルの組み合わせで得られたエコー高さを各荷重時に おいて抽出した。図-16において，横軸は載荷荷重，縦 軸はエコー高さを示している. 縦軸のエコー高さは最 大時を基準とした相対高さとしている. 図-16(a) は 30 万回載荷後のビーチマークのスケッチおよび探傷位置 を示している．探触子位置と波動伝播距離より，送信お よび受信がともに 1 チャンネルの波形は，未溶着部上端 
(a) 探傷位置 A-A'
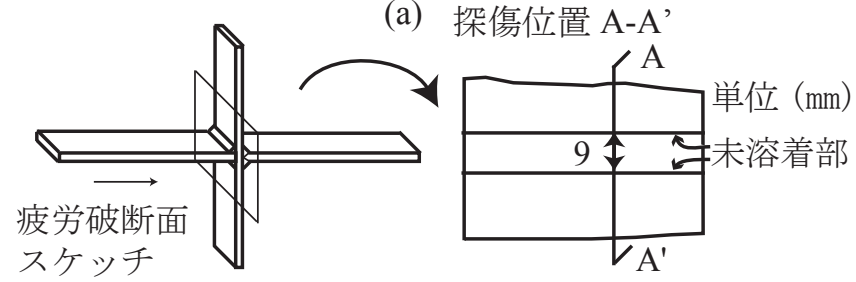

30万回載荷時のビーチ マーク(き裂なし)

(b)
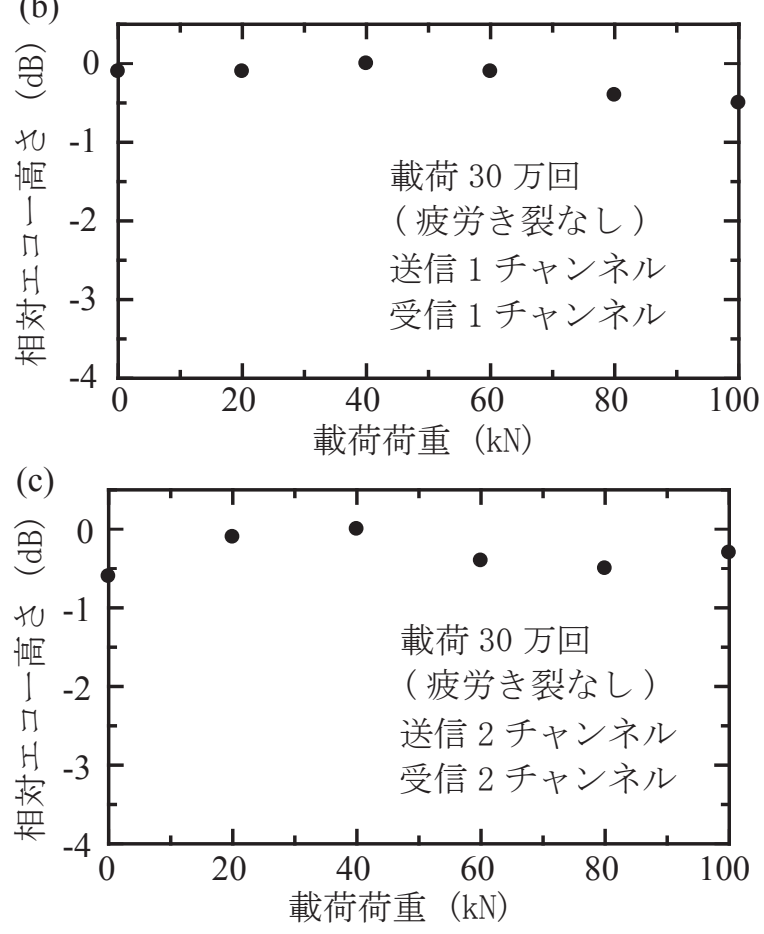

(d) 探傷位置 A-A'

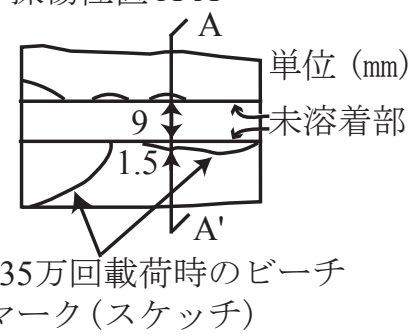

(e) マーク(スケッチ)

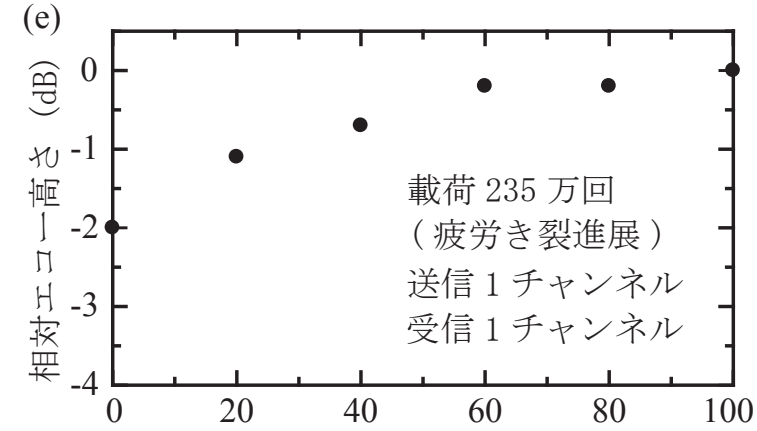

(f)

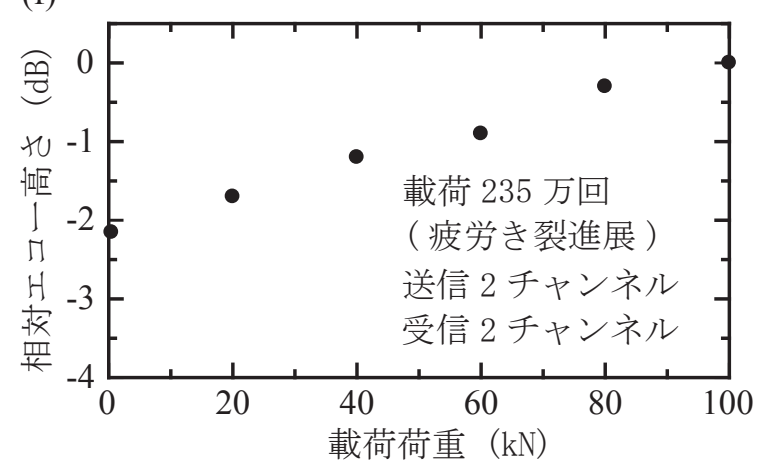

図-16 荷重とエコー高さ : 板厚 $t=25 \mathrm{~mm}$, 未溶着部高さ $h=9 \mathrm{~mm}$ 試験体 30 万回および 235 万回載荷後

部からのエコーを，送信および受信がともに 2 チャン ネルの波形は，下端部からのエコーである．図-16(b), (c) より, 30 万回載荷後において, 各荷重載荷時で上下 端部エコーと思われるエコーの高さはそれほど変化し ていないことがわかる．図-16(a)に示すように，30万 回載荷時においては疲労き裂は発生しているようには 見えず，探傷試験結果からも疲労き裂の開口現象はと らえられなかった。

荷重 235 万回載荷後のビーチマークを図-16(d) に示 す，送信受信ともに 1 チャンネルの組み合わせ，およ びともに送受信 2 チャンネルの組み合わせのエコーと 荷重の関係を図-16(e) および (f) に示寸. 荷重が大きく なるにつれて, エコー高さが高くなる傾向が見られる. 未溶着部下端からは疲労き裂が $1.5 \mathrm{~mm}$ の長さにまで進 展している. 図-16(d) では, 未溶着部上端から進展す る疲労き裂は肉眼ではとらえられなかったが，図-16(e) に示すエコー高さが変化していることからき裂が進展 していた可能性がある. 図-16に示した例ではき裂進展 長さが短いため, エコー高さの変化も $2 \mathrm{~dB}$ 程度と, そ れほど大きくならなかったものと思われる.
ここでの検討より, き裂進展後の荷重載荷によるき 裂先端開閉口挙動を超音波探傷試験でとらえることが できた．開閉口挙動を示すのは端部エコーのみである ことも確認された.

未溶着部より疲労き裂が進展している場合，き裂開 口時に得たエコーにより再構成された画像は, き裂閉 口時に得たエコーにより再構成された画像に対して, 端 部エコーの情報を含んでいるといえる。つまり，き裂 開口時の画像よりき裂閉口時の画像を差し引いた画像 は端部エコーの情報のみを取り出すことができると考 えられる。

厚さ $25 \mathrm{~mm}$, 未溶着部の高さ $15 \mathrm{~mm}$ の試験体に対し て, 荷重載荷 23 万回でのデータを用いてき裂端部検出 を試みた。図-17(a) は試験体において, 疲労破断面お よび再構成画像がどのような方向から見たものかを示 している. 図-17(b) は画像再構成を行った 23 万回載荷 時のビーチマークのスケッチである. 図-17(c) は疲労 破断後の断面の写真である. 図-17(d) は探傷位置での 未溶着部と疲労き裂の進展状況を模式的に示したもの である．板幅方向の探傷位置は図-17(b) および (c) に示 


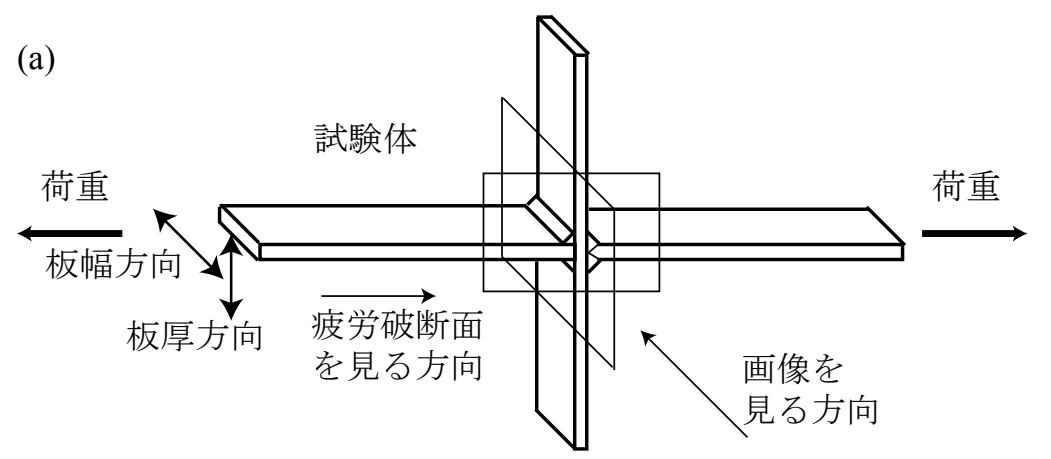

(b) 探傷位置 A-A'

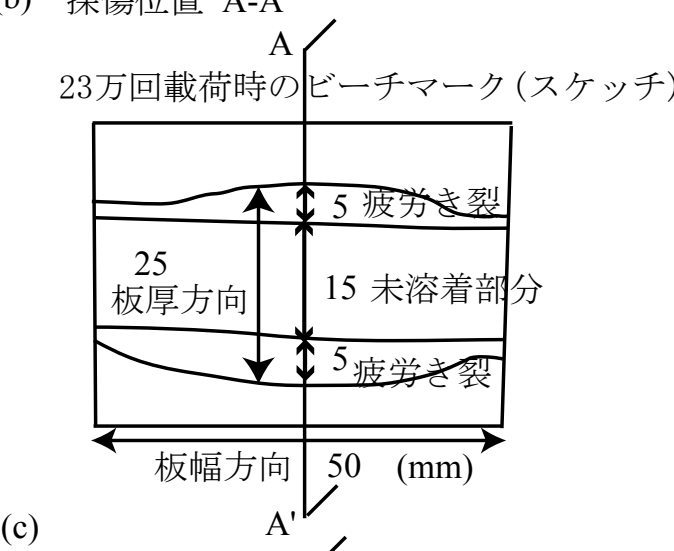

(d) A-A'断面

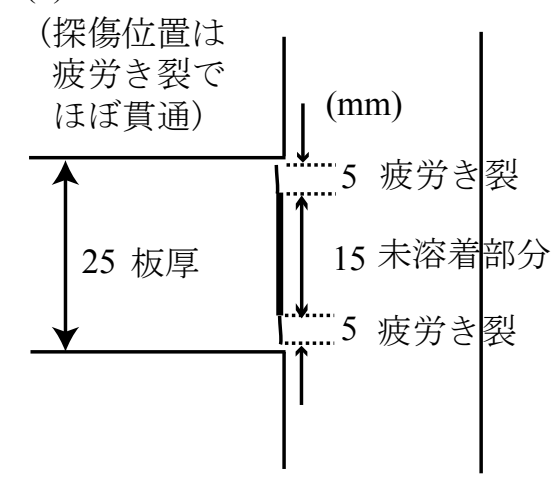

(e)

画像化結果

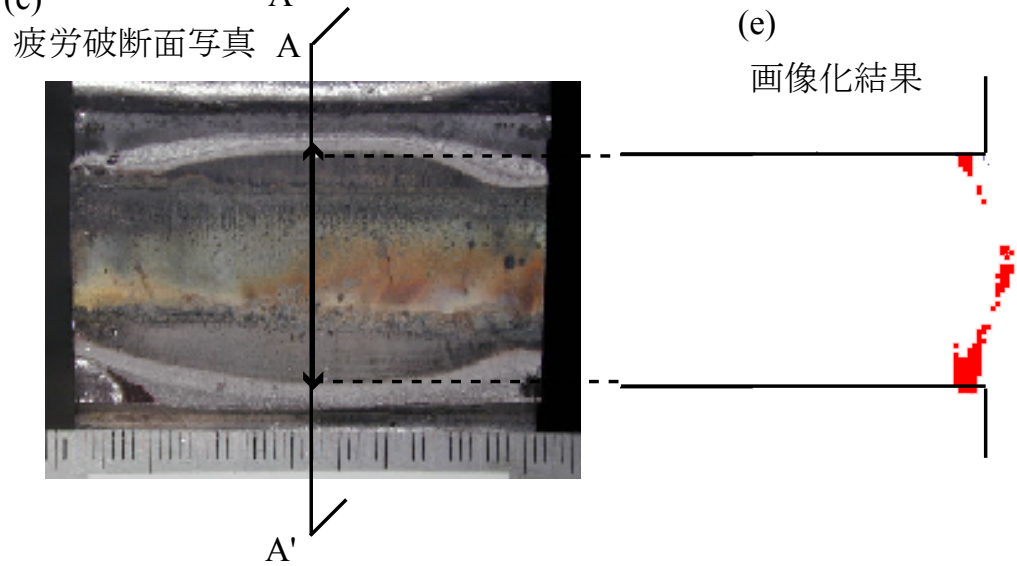

図-17 載荷時より除荷時の波形を差し引いた波形による画像化結果 板厚 $t=25 \mathrm{~mm}$, 未溶着部高さ $h=15 \mathrm{~mm}$ 試験体 23 万回 載荷後

されている. 図-17(b) に示すように疲労き裂は板幅中 央部において母材板厚とほぼ同じにまで進展している.

図-17(e) は $80 \mathrm{kN}$ 載荷時の波形から $0 \mathrm{kN}$ 載荷時の波 形の振幅を引き算したあとの波形で画像化した結果で ある．上下の表面近傍に像が現れていることがわかる. これらの像の位置はき裂先端位置と同様である．板厚 中央付近に見られる円弧状に得られている像は, 開口 合成において考慮した入射超音波ビームの広がりによ るものである ${ }^{11)}$.

厚さ $25 \mathrm{~mm}$, 未溶着部高さ $9 \mathrm{~mm}$ の試験体において, 235 万回荷重をかけた際の探傷試験結果より, 端部エ コー抽出を試みた結果を図-18 に示す，図-17 と同様， 図-18(a) は試験体と破断面および画像を見る方向の関 係を示している。また, 図-18(b) は探傷試験を行った 235 万回載荷時のビーチマークのスケッチ, 図-18(c) は
疲労破断面の写真, 図-18(d) は 235 万回載荷時の疲労 き裂進展状況，図-18(e) は $100 \mathrm{kN}$ 載荷時に得られた波 形から $0 \mathrm{kN}$ 載荷時の波形を引いたのちの波形より再構 成した像である. 図-16に示したように, 荷重載荷によ るエコー高さの増加が図-15 に示寸試験体よりも小さ かったために, き裂端部付近のみに像が得られている. 図-18(b) に示寸写真では上端部からの疲労き裂の確認 は困難であったが，き裂は進展していた。画像による 久陷端部と実際のき裂先端はよく一致していることが わかる。

\section{6. まとめ}

本研究で得られた結果をここにまとめる.

(1) タンデムアレイ探触子により, 溶接未溶着部を検出 
(a)

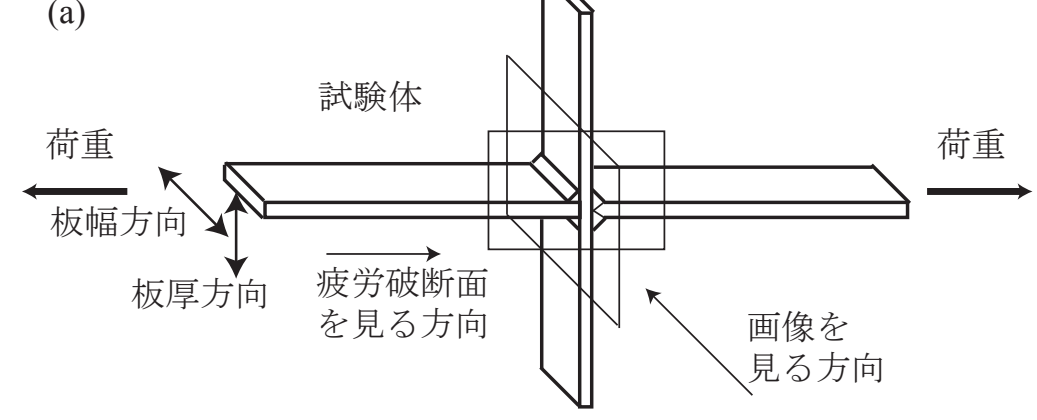

(b)

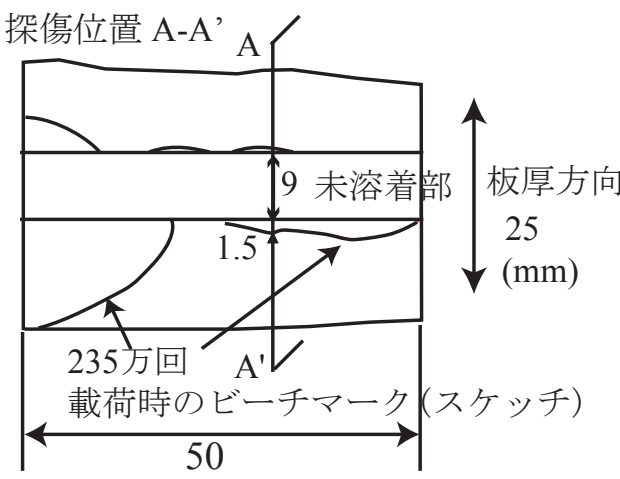

(c) 疲労破断面写真

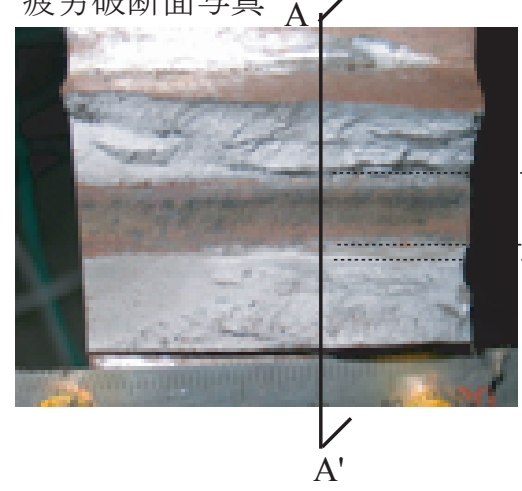

(d) A-A' 断面

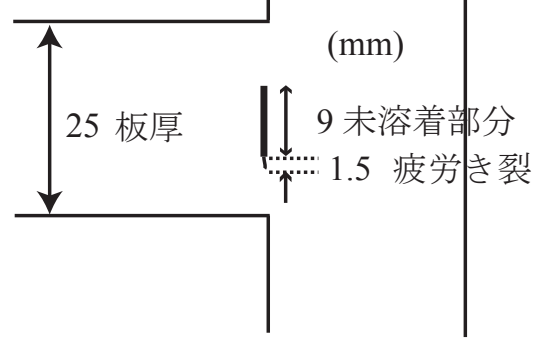

(e)

画像化結果

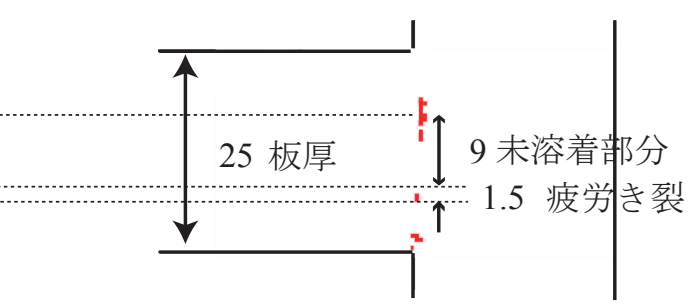

図-18 載荷時より除荷時の波形を差し引いた波形による画像化結果 板厚 $t=25 \mathrm{~mm}$, 未溶着部高さ $h=9 \mathrm{~mm}$ 試験体 235 万回 載荷後

した．探触子位置により得られるエコー高さの変化を 調べた。探触子を柱面に十分近い位置に置けば未溶着 部からのエコーを受信できることが示された。

(2) 開口合成による画像化で未溶着部の高さを推定し た。高さは十分精度よく推定された。

(3) 疲労き裂の開閉口によるエコー高さの変化をコンパ クトテンション試験片および十字継手試験片で確認し た.

（4）載荷時と非載荷時の画像の振幅の差をとることによ り端部エコーの発生源位置を特定することができた。

本研究の結果は $\mathrm{K}$ 開先溶接未溶着部より進展した疲 労き裂検出に適用できると考えるが，今後としては，き 裂進展量, 載荷荷重と端部エコー高さ変化量の関係を 調べることが課題である.
謝辞: 本研究は文部科学省科学研究費補助金 (基盤研 究 $\mathrm{A}$ 代表:三木千壽) を受けて実施されました.ここに 記して関係各位に謝意を表します.

\section{参考文献}

1) 森河 久, 下里 哲弘, 三木 千壽, 市川 篤司: 箱断面を有す る鋼製橋脚に発生した疲労損傷の調查と応急対策, 土木 学会論文集, No.703/I-59, pp.177-183, 2002.

2) 三木 千壽, 平林 泰明, 時田 英夫, 小西 拓洋, 柳沼 安俊: 鋼製橋脚隅角部の板組鋼製と疲労き裂モード, 土木学会 論文集, No.745/I-65, pp.105-119, 2003.

3) 鋼構造委員会疲労変状調査小委員会: 鋼橋の疲労変状調 査, 土木学会論文集, No.368/I-5 pp.1-12, 1986.

4) Fisher, J.W.: 鋼橋の疲労と破壊, 建設図書, 1987.

5) 構造工学委員会非破壊評価小委員会: 土木構造, 材料の 定量的非破壊評価へのアプローチ (委員会報告), 土木学 会論文集, No.428/I-15, pp.1-18, 1991.

6) 構造工学委員会非破壞評価小委員会: 土木工学における 非破壊評価の現状と将来 (委員会報告), 土木学会論文集, No.459/I-22, pp.1-18, 1993.

7) 西村 直志, 廣瀬 壮一: 逆問題と非破壊検査, 構造工学論 
文集, Vol.37A, pp.425-434, 1991.

8) 北原 道弘, 羽田 幸寿: 後方散乱振幅スペクトルの周期性 を利用したステンレスクラッド鋼界面のクラック長の計 測, 構造工学論文集, Vol.45A pp.321-327, 1999.

9) 三上 修一, 大島 俊之, 菅原 登, 山崎 智之: エコー波形の 詳細解析による超音波探傷法の欠陥検出の定量的評価, 土木学会論文集, No.509/I-29, pp.103-112, 1994.

10) Sugawara, N., Oshima, T., Mikami, S. and Sutiura, S.: On the accuracy improvement in ultrasonic inspection by using computer graphics and waveform analysis, Structural Eng./Earthquake Eng.(Proc. of JSCE) pp.247s-256s, 1993.

11) 三木 千壽, 白旗弘実, 西田 朱里, 柳沼 安俊: タンデムアレ イ探触子による突き合わせ溶接継手の超音波非破壊検査 特性, 土木学会論文集, No.654/I-52, pp.131-142,2000.
12) Rattanasuwannachart, N., Takahashi, K., Miki, C. and Hirose, S.: Development of 3D Flaw Detection System with Multi-channel Planar Array Probes and 3D SAFT Algorithms, Structural Eng./Earthquake Eng., JSCE, Vol.22, No.1, pp.27s-39s, 2005. (Journal of Struct. Mech. Earthquake Eng., JSCE, No.787/I71)

13）三木千寿, 豊田幸宏, 宮本公男, 梅田晶一 : 超音波を用 いた疲労亀裂の検出, 構造工学論文集, Vol.33A,pp.383391,1987.3.

14）渡辺一弘, 三木千壽, 舘石和雄 : 端部エコー法による疲労 亀裂開閉口の観察, 土木学会第 49 回年次学術講演会講演 概要集第 1 部,pp.600-601,1994.9.

\section{NONDESTRUCTIVE EVALUATION AND FATIGUE CRACK DETECTION OF DOUBLE BEVEL T-JOINT BY ULTRASONIC TESTING}

(2006.12.26 受付)

Chitoshi MIKI, Hiromi SHIRAHATA, Ryota YAMAGUCHI, Koji KINOSHITA and Yasutoshi YAGINUMA

Double bevel T-joint is one of the most fundamental joints of steel bridges. Double bevel Tjoint can be seen at beam-column connection of bridge piers. In the Japanese specifications, the welding should be full penetration. Fatigue cracks can be propagated from the weld defects such as incomplete penetration. Incomplete penetration should be avoided. The authors have developed a tandem array transducer. Specimens of double bevel T-joint were made. Ultrasonic test was conducted for those specimens. Detectability of incomplete penetration was investigated. Image reconstruction of incomplete penetration by synthetic aperture focusing technique was carried out. Height of incomplete of penetration could be estimated accurately. When a fatigue crack exists in a welded joint, crack tip opening occurs. Crack tip opening can be observed by echo height from the crack tip. Fatigue crack could be detected by comparing echo height between when load was applied and no load was applied. 